\title{
Effect of a diamond-like carbon film on the mechanical and surface properties of
}

\section{microwave-cured polymethylmethacrylate}

Efeito de película de carbono tipo diamante nas propriedades mecânicas e de superfície de polimetilmetacrilato polimerizado por microondas

Efecto de película de carbono tipo diamante sobre las propiedades mecánicas y superficiales del polimetilmetacrilato polimerizado por microondas

Pâmela Lopes Pedro da Silva ORCID: https://orcid.org/0000-0003-4537-6821 Federal University of Paraíba, Brazil E-mail: pamelapan_lopes@hotmail.com

George Azevedo Lemos ORCID: https://orcid.org/0000-0002-2140-216X Federal University of Alagoas, Brazil E-mail: george.lemos@icbs.ufal.br

Frederico Barbosa de Sousa ORCID: https://orcid.org/0000-0002-9158-8342 Federal University of Paraíba, Brazil E-mail: fredericosousa@hotmail.com

Argemiro Soares da Silva Sobrinho ORCID: https://orcid.org/0000-0001-7227-9176 Technological Institute of Aeronautics, Brazil E-mail: argemirosss@gmail.com

José Renato Cavalcanti de Queiroz ORCID: https://orcid.org/0000-0001-8573-0288 Potiguar University, Brazil E-mail: joserenatocq@hotmail.com André Ulisses Dantas Batista ORCID: https://orcid.org/0000-0003-1593-0174 Federal University of Paraíba, Brazil E-mail: andreulisses@yahoo.com.br

\begin{abstract}
Introduction: Microwave-cured polymethylmethacrylate (MCPM) are commonly used in dentistry due low cost, transparency and easy handling. However, do not have a long useful life, due to their chemical fragility and low hardness and wear resistance. Aim: Assessing the effect of a diamond-like carbon (DLC) film coating on the mechanical and surface properties of MCPM. Methodology: The MCPM samples were divided into control (Gc) and treatment $(\mathrm{Gt})$ groups, and were subjected to flexural strength $(\mathrm{n}=18)$, wear resistance $(\mathrm{n}=18)$ tests, and to topography and surface roughness $(\mathrm{Ra})$ analysis by three-dimensional optical profilometry $(\mathrm{n}=18)$. The films were deposited by plasma-enhanced chemical vapor deposition. Differences between groups were assessed by the Mann-Whitney and $t$ tests using a 5\% significance level $(\mathrm{p}<0.05)$. Results: The Gt had higher surface roughness $(0.108 \pm 0.01 \mu \mathrm{m})$ than the Gc $(0.038 \pm 0.01 \mu \mathrm{m})$, with $\mathrm{p}<0.0001$. No significant difference $(\mathrm{p}=0.606)$ in flexural strength was found between $\mathrm{Gt}$ (103.3 MPa) and Gc (105.3 MPa). No significant difference was found between the groups in terms of straightness (Gt: $0.006 \pm 0.0059 \mathrm{~mm}$ and Gc $0.005 \pm 0.0052 \mathrm{~mm}, \mathrm{p}=0.774$ ) or indentation depth (Gt: $29.974 \pm 8.69 \mu \mathrm{m}$ and Gc: $28.169 \pm 5.71 \mu \mathrm{m}, \mathrm{p}=0.610$ ) after the wear test. Conclusion: Coating the MCPM surface with a DLC film affected the surface roughness, with no effects on flexural strength and wear resistance. New studies are suggested to better understand these effects, perhaps with variations in the deposition parameters such as coating thickness or on the sp3/sp2 ratio.
\end{abstract}

Keywords: Diamond-like carbon; Polymethyl methacrylate; Surface roughness; Wear resistance; Flexural strength.

\section{Resumo}

Introdução: Polimetilmetacrilato polimerizado por micro-ondas (MCPM) é comumente utilizado na Odontologia devido baixo custo, transparência e fácil manuseio. No entanto, não possui vida útil longa, devido fragilidade química e baixa dureza e resistência ao desgaste. Objetivo: Avaliar efeito de revestimento com filme de carbono tipo diamante (DLC) nas propriedades mecânicas e de superfície do MCPM. Metodologia: Amostras de MCPM foram divididas em 
grupos controle $(\mathrm{Gc})$ e tratamento $(\mathrm{Gt})$, e submetidas a testes de resistência à flexão $(\mathrm{n}=18)$, resistência ao desgaste $(n=18)$ e análise de topografia e rugosidade superficial $(\mathrm{Ra})$ por perfilometria óptica tridimensional $(\mathrm{n}=18)$. Os filmes foram depositados por deposição de vapor químico assistido por plasma. As diferenças entre os grupos foram avaliadas pelos testes t e Mann-Whitney com nível de significância de 5\% (p<0,05). Resultados: Gt apresentou maior rugosidade superficial $(0,108 \pm 0,01 \mu \mathrm{m})$ que $\mathrm{Gc}(0,038 \pm 0,01 \mu \mathrm{m})$, com $\mathrm{p}<0,0001$. Não foi encontrada diferença significativa $(\mathrm{p}=0,606)$ na resistência à flexão entre $\mathrm{Gt}(103,3 \mathrm{MPa})$ e $\mathrm{Gc}(105,3 \mathrm{MPa})$. Não foi encontrada diferença significativa entre os grupos em relação à retidão (Gt: $0,006 \pm 0,0059 \mathrm{~mm}$ e Gc $0,005 \pm 0,0052 \mathrm{~mm}, \mathrm{p}=0,774)$ ou

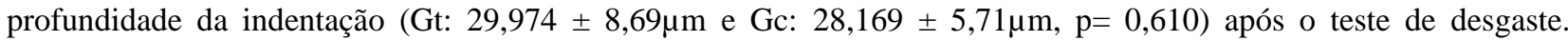
Conclusão: O revestimento de MCPM com filme de DLC afetou a rugosidade da superfície, sem efeitos na resistência à flexão e resistência ao desgaste. Novos estudos são sugeridos para entender melhor esses efeitos, talvez com variações nos parâmetros de deposição como espessura do revestimento ou na relação sp3/sp2.

Palavras-chave: Carbono tipo diamante; Polimetilmetacrilato; Rugosidade superficial; Resistência ao desgaste; Resistência à flexão.

\section{Resumen}

Introducción: El polimetilmetacrilato polimerizado por microondas (MCPM) es de uso común en Odontología debido a su bajo costo, transparencia y fácil manejo. Sin embargo, no tiene una larga vida útil debido a la fragilidad química y la baja dureza y resistencia al desgaste. Objetivo: Evaluar el efecto del recubrimiento de película de carbono tipo diamante (DLC) sobre las propiedades mecánicas y superficiales de MCPM. Metodología: Las muestras de MCPM se dividieron en grupos de control $(\mathrm{Gc})$ y tratamiento $(\mathrm{Gt})$, y se sometieron a pruebas de resistencia a la flexión $(\mathrm{n}=18)$, resistencia al desgaste $(n=18)$ y análisis de topografía y rugosidad superficial (Ra) por perfilometría óptica tridimensional $(\mathrm{n}=18)$. Las películas se depositaron mediante deposición de vapor químico asistida por plasma. Las diferencias entre grupos se evaluaron mediante las pruebas t y Mann-Whitney con un nivel de significación del 5\% $(\mathrm{p}<0,05)$. Resultados: Gt mostró mayor rugosidad superficial $(0,108 \pm 0,01 \mu \mathrm{m})$ que Gc $(0,038 \pm 0,01 \mu \mathrm{m})$, con $\mathrm{p}<0,0001$. No se encontró diferencia significativa $(\mathrm{p}=0,606)$ en la resistencia a la flexión entre Gt $(103,3 \mathrm{MPa})$ y Gc $(105,3 \mathrm{MPa})$. No se encontraron diferencias significativas entre los grupos con respecto a la rectitud (Gt: $0,006 \pm$ $0,0059 \mathrm{~mm}$ y Gc $0,005 \pm 0,0052 \mathrm{~mm}, \mathrm{p}=0,774)$ o profundidad de indentación (Gt: 29,974 \pm 8,69 $\mu \mathrm{m}$ y Gc: $28,169 \pm$ $5,71 \mu \mathrm{m}, \mathrm{p}=0,610)$ después de la prueba de desgaste. Conclusión: El recubrimiento de MCPM con película de DLC afectó la rugosidad de la superficie, sin efecto sobre la resistencia a la flexión y la resistencia al desgaste. Se sugieren más estudios para comprender mejor estos efectos, quizás con variaciones en los parámetros de deposición, como el espesor del recubrimiento o la relación $\mathrm{sp} 3 / \mathrm{sp} 2$.

Palabras clave: Carbono tipo diamante; Polimetilmetacrilato; Rugosidad superficial; Resistencia al desgaste; Resistência flexional.

\section{Introduction}

Polymethylmethacrylate (PMMA), commonly known as acrylic resin, is a hydrophilic bioinert polymer (Ykada, 1994) whose main advantages are low cost, transparency and easy handling (Ban et al., 2009; Ohtake, et al., 2012). Since its inception more than 80 years ago, PMMA has been widely used in dentistry, especially in the areas of prosthodontics and oral rehabilitation (Barbosa, et al., 2003). The desirable mechanical, optical and electrical properties and biocompatibility enable the use of PMMA to fabricate occlusal splints and orthodontic appliances and prostheses, whether total, partial, provisional or over-implant (Barbosa, et al., 2003; Corazza, et al., 2014; Li, et al., 2000; Lin, et al., 2008; Ohtake, et al., 2012; Sharma, et al., 2010; Zhang, et al., 2016).

Pure PMMA is a colorless and transparent solid, which can be pigmented according to its use. It is supplied in a powder-liquid system, where the liquid contains unpolymerized methylmethacrylate resin and a small amount of hydroquinone, while the powder contains prepolymerized poly(methylmethacrylate) resin in the form of pearls and a small amount of benzoyl peroxide. Hydroquinone acts as an inhibitor, preventing unwanted polymerization; benzoyl peroxide is responsible for initiating the polymerization process (Anusavice, 2005).

The thermal energy required for the polymerization of PMMA can come from both a water bath (conventional technique) and a microwave oven. The polymerization of the resin by microwave energy has been used to the detriment of the conventional technique, with the advantages of reducing the time of polymerization and cleaning during processing and still maintaining its properties and characteristics (Anusavice, 2005; Barbosa, et al., 2003). 
Dental devices made of PMMA do not have a long useful life, mainly due to their chemical fragility and low hardness and wear resistance, leading to their high degradation and consequent release of irritant products (residual monomers) to the oral tissues (Ban \& Yuhara, 2009; Lin, et al., 2008; Ohtake, et al., 2012; Sharma, et al., 2010). Many attempts have been made to improve its mechanical properties, whether with chemical modifications or not, through the addition of metals, fibers and ceramic particles. However, these methods can present several obstacles, such as non-adhesion of the resin to the material chosen as reinforcement, corrosion, the need for specific equipment and specialized labor and high cost, in addition to factors related to its biocompatibility (Lin, et al., 2008; Sharma, et al., 2010).

Most conventional materials have good functionality, but their surface characteristics limit their use as biomaterials (Ykada, 1994; Dearnaley et al., 2005; Sharma, et al., 2010; Silva, et al., 2019). In the case of acrylic resin, its high porosity and surface roughness are predisposing factors for the retention of microorganisms when used in the oral cavity (Machado, et al., 2012; Queiroz, et al., 2013; Robertson, 2002; Sorgini, et al., 2012). For use of dental devices, recommended a mechanical cleaning with toothbrushes and coadjutant methods of chemical disinfection such as immersion in chemical agents, but some points must be noted in this combination after long-term: the mechanical cleansing remove a superficial material, affecting the physical properties of PMMA such as increased surface roughness and reduced flexural strength; moreover the chemical cleansing residues of may result in some degree of toxicity to the device-bearing mucosa after daily immersion (Kiesow, et al., 2016; Procópio, et al., 2018).

Thus, a biocompatible coating able to reduce the susceptibility of acrylic resin to wear would be important to extend the useful life of dental prostheses and occlusal splints (Ban et al., 2009; Li, et al., 2000; Queiroz, et al., 2013). Among the possible surface treatments, diamond-like carbon (DLC) has several desirable properties, including high hardness, a low friction coefficient, chemical inertia, high electrical resistance, transparency and biocompatibility (Akaike, et al., 2015; Dearnaley et al., 2005; Li, et al., 2000; Lin, et al., 2008; Robertson, 2002; Silva, et al., 2019).

The applicability of DLC to various fields has been studied since the 1970s. (Akaike, et al., 2015; Dearnaley et al., 2005; Lifshitz, 1999; Sharma, et al., 2010; Silva, et al., 2019; Ykada, 1994). Its capacity to adhere to a wide range of materials, such as metals (Akaike et al., 2015), plastics, polymers, has been attractive to biomedical engineering researchers for the manufacture of more resistant and biocompatible prostheses, implants and medical instruments (Akaike et al., 2015; Lifshitz, 1999; Sharma, et al., 2010; Silva, et al., 2019).

The DLC film can be deposited using several techniques, although they all involve some type of ionic bombardment, which can be accomplished through physical or chemical vapor deposition (Akaike, et al., 2015; Dearnaley et al., 2005). Some chemical elements may also be added to its structure to modify its characteristics according to its use. The addition of silver or fluorine ions can, for example, add antimicrobial properties to the material, thereby decreasing the formation and adhesion of bacterial biofilm (Queiroz, et al., 2013; Sharma, et al., 2010; Silva, et al., 2019).

The objective of this study was to assess the effect of DLC film coating on the mechanical and surface properties of microwave-cured polymethylmethacrylate (MCPM). Few studies have used DLC film in dentistry, particularly in the area of dental prosthesis, (Queiroz, et al., 2013) and its repercussions when applied to this type of material are not yet fully known. Despite already knowing the antimicrobial activity and biocompatibility of the DLC, more studies are needed to ensure its viability in relation to its mechanical behavior when used in acrylic resin.

\section{Methodology}

\subsection{Preparation of microwave-cured polymethylmethacrylate (MCPM) samples}

108 MCPM samples (VipiWave, Vipi, São Paulo, Brazil) were prepared by embedding fluid wax impressions in fiber 
glass muffles and activating polymerization according to the manufacturer's instructions. The MCPM specimens were finished and polished using wet sandpaper with decreasing grit (150,240,400, 600 and 1200) and a felt disc with aluminum paste mounted on a polisher at $100 \mathrm{rpm}$, under water cooling (Arapol E, Arotec, São Paulo, Brazil). To remove polishing debris, the specimens were immersed in an ultrasound bath (BioWash STD, Bio Art, São Paulo, Brazil) in distilled water for 15 minutes, carefully dried with absorbent paper and stored in individual flasks. For standardization, the samples were prepared by a single researcher and randomly divided into $\mathrm{Gc}$ - control group ( $\mathrm{n}=54)$ and $\mathrm{Gt}$ - treatment group $(\mathrm{n}=54)$, according to previous sample calculation. (Cohen, 1988).

\subsection{Diamond-like carbon film coating}

The DLC films were deposited on the surface of the microwave-cured polymethylmethacrylate. Gt specimens were coated with DLC through plasma-enhanced chemical vapor deposition (PECVD) technique for 60 minutes. The process was performed in a vacuum chamber using $50 \mathrm{sscm}$ of hydrogen and $10 \mathrm{sccm}$ of methane and the plasma was generated using a 13.56 MHz RF power supply (ENI, model ACG-10B-01, Andover, MA, USA) and set up in 100W. The base pressure of the system was $6.7 \times 10-3 \mathrm{~Pa}$. The deposited coating were $250 \mathrm{~nm}$ thick. An initial hydrogen discharge was used to eliminate surface contamination in the target, following a previous report (Queiroz, et al., 2013).

\subsection{Flexural strength test}

The three-point flexural strength test simultaneously measures the tensile (force per unit area), compressive and bending strengths of a rod-shaped test piece (Anusavice, 2005), and is the mechanical test recommended by the International Organization for Standardization when used PMMA for dentistry (ISO, 2013). For the three-point flexural strength test $(\mathrm{n}=18)$, the specimens (64 mm long, $10 \mathrm{~mm}$ wide and $3.3 \mathrm{~mm}$ thick) were placed on a universal mechanical testing machine (Instron 3365, Instron Corporation, Nordwood, MA, USA) fitted with a $5 \mathrm{kN}$ load cell and calibrated to a $5 \mathrm{~mm} /$ minute constant speed. Each specimen was fixed at two points, one at each end, with the DLC-coated surface facing down (in the case of Gt), and at a third fixed point to apply the force to the center of the test piece, in the opposite direction to the supports, gradually, until fracture. Before the test, the specimens were individually stored in distilled water in an oven at $37^{\circ} \mathrm{C}$ for 48 hours (Barbosa, et al., 2003; ISO, 2013).

\subsection{Wear resistance test}

Wear is the volume of material removed from the sample during the relative movement between two surfaces in contact (Robertson, 2002). The wear resistance test $(n=18)$ was performed using a biaxial universal testing machine (InstronE10000, Instron Corporation, Nordwood, MA, USA). Each specimen (4 mm in diameter and $20 \mathrm{~mm}$ thickness) was fixed to the wedge grip of the machine, exposing one end of the specimen. The round-tip plunger performed a cyclical motion, and a $200 \mathrm{~N}$ load at a $15^{\circ}$ amplitude and a $1.6 \mathrm{~Hz}$ frequency was applied, totaling 1000 cycles. The motion of the plunger on the sample caused surface wear in the shape of well-defined elliptical indentations.

Before and after the test, the specimens were measured using a coordinate measuring machine (Crysta-Apex S 574, Mitutoyo Corporation, Kawasaki, Japan) to assess differences in straightness and, thus, to identify the types of wear experienced in both groups. Three points on a $2 \mathrm{~mm}$ path were measured in each specimen, using a $0.1 \mathrm{~mm}$ tolerance zone above and below.

After the wear test, the specimen was subjected to surface analysis using a non-contact 3D optical profiler (CCI MP, Taylor Hobson, England). A $0.25 \mathrm{~mm}$ cutoff was used with a 10X objective, a 0.3 numerical aperture, and a $1 \mathrm{X}$ scanning speed 
in XYZ mode (512 x 512 resolution) using a stitching configuration to observe the entire area of indentations formed in the material. Using the software Talysurf CCI (Taylor Hobson, England), two perpendicular lines were drawn on each image obtained, forming a cross with the point of intersection at the center of the indentation, and the two deepest areas of each line were selected; thus, based on the means of these values, the depth $(\mu \mathrm{m})$ of each sample was calculated, making it possible to assess possible differences in wear between groups.

\subsection{Topography and surface roughness}

The specimens (10 $\mathrm{mm}$ in diameter and $4 \mathrm{~mm}$ in height) were subjected to surface analysis $(\mathrm{n}=18)$ to assess their topography and measure the surface roughness using a non-contact 3D optical profilometer (CCI MP, Taylor Hobson, England) connected to a computer unit with the software Talysurf CCI (Taylor Hobson, England) for data collection. A 0.25 mm cutoff was used with a 20X lens, a 0.4 numerical aperture and a 5X scanning speed in XY mode (1024 x 1024 resolution). The mean surface roughness $(\mathrm{Ra})$ is the mean of the absolute values of the heights of the peaks and valleys in the sample surface in relation to the center plane (Venâncio, 2005). Five measurements were taken for each specimen (one in the central area and the others according to the movement of the $2 \mathrm{~mm}$ lens up, down, to the right and to the left, along the drawing of a cross), from which the Ra of each specimen was assessed (Queiroz, et., 2013; Sorgini, et al., 2012).

\subsection{Statistical analysis}

The results were tabulated in SPSS (Statistical Package for the Social Sciences) version 19.0 and were subjected to the Shapiro-Wilk normality test. The surface roughness $(\mathrm{Ra})$ and straightness data showed normal distributions, and the difference between the groups ( $\mathrm{Gc}$ and $\mathrm{Gt}$ ) was assessed using the t test. Conversely, the flexural strength and indentation depth data showed non-normal distributions, and the non-parametric Mann-Whitney test was applied. A 5\% significance level was adopted for all tests performed. The surface topography of the samples was analyzed qualitatively.

\section{Results}

\subsection{Flexural strength}

The flexion strength values were 103.3 MPa (interquartile range [IQR] 97.67 \pm 110.32) for Gt and 105.3 MPa (IQR $98.95 \pm 109.06$ ) for Gc (Figure 1a). No statistically significant difference was found between the groups, with $\mathrm{p}=0.606$. Thu $\mathrm{s}$, DLC film surface coating of MCPM had no effect on flexural strength.

\subsection{Wear resistance}

The straightness values obtained after the wear test was $0.006 \pm 0.0059 \mathrm{~mm}$ for Gt and $0.005 \pm 0.0052 \mathrm{~mm}$ for Gc, with $\mathrm{p}=0.774$ (Figure 1b). Additionally, the indentation depth assessed on the surface of the samples after the wear test was $30.43 \mu \mathrm{m}$ for Gt (IQR $24.19 \pm 36.68)$ and $30.08 \mu \mathrm{m}$ (IQR $28.16 \pm 38.20$ ) for Gc, with p=0.81 (Figure 1c). No statistically significant difference was found between the groups, thus DLC film did not affect MCPM straightness and indentation depth, and for that reason DLC film surface coating of MCPM had no effect on wear resistance.

\subsection{Surface roughness}

The treatment group had a significantly higher mean surface roughness $(0.108 \pm 0.013 \mu \mathrm{m})$ than the control group $(0.038 \pm 0.010 \mu \mathrm{m})$, with $\mathrm{p}<0.0001$, as shown in Figure 1d. Therefore, DLC film increased MCPM surface roughness by 2.8 times. 
Figure 1 - For the control $(\mathrm{Gc})$ and treatment (Gt) groups - (a) Flexural strength values in MPa (median $\pm \mathrm{IQR})$; (b) Straightness values (mean $\pm \mathrm{SD}$ ) in $\mathrm{mm}$ after the wear test; (c) Indentation depth values (median $\pm \mathrm{IQR}$ ) in $\mu \mathrm{m}$ after the wear test; (d) Surface roughness $(\mathrm{Ra})$ values in $\mu \mathrm{m}(\mathrm{mean} \pm \mathrm{SD})$.

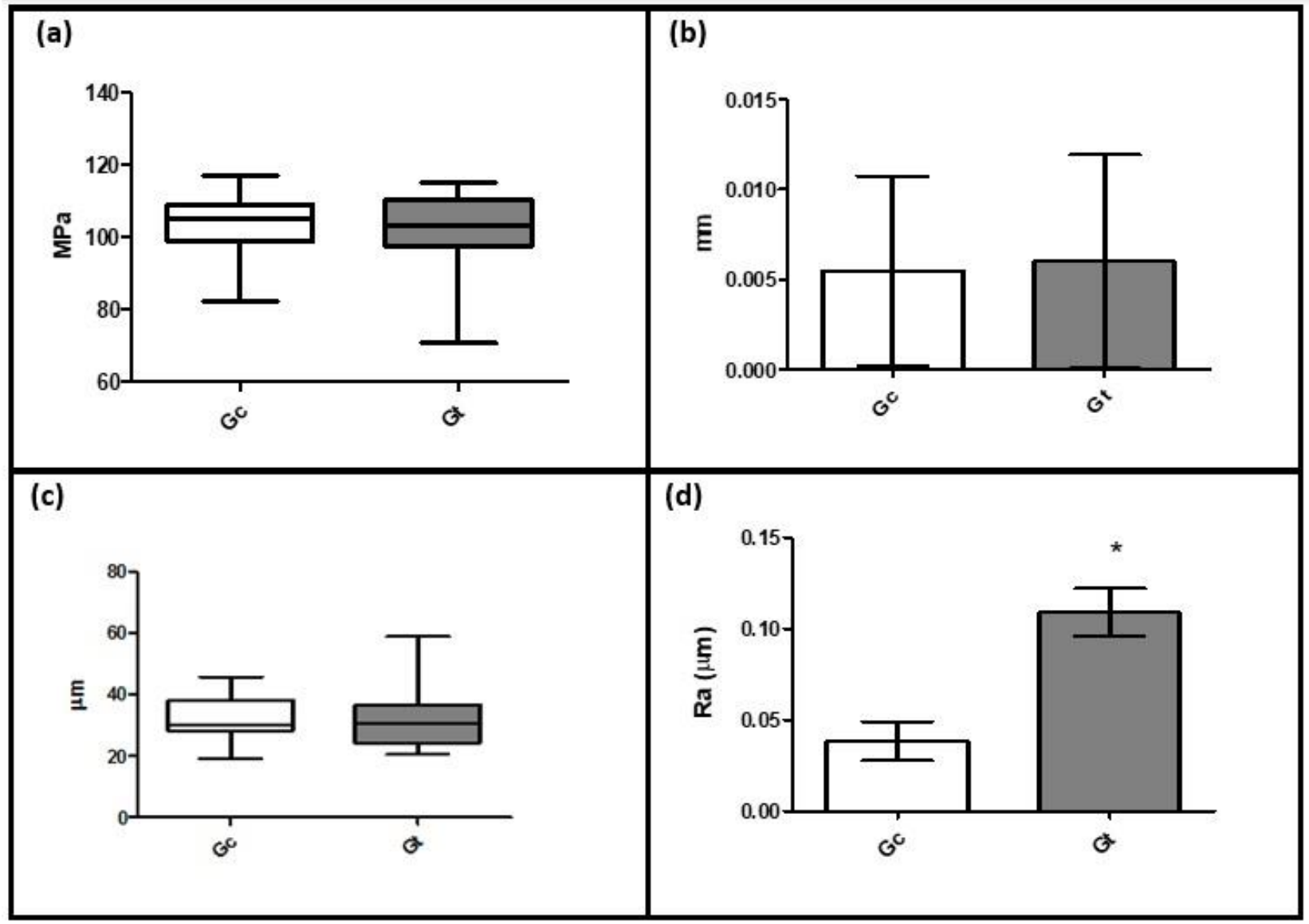

*Significant difference, $\mathrm{p}<0.0001$. Source: Authors (2022).

\subsection{Surface topography}

Figure 2A and 2B shows the visual aspect of the indentations formed on the surfaces of the samples of both groups after the wear test, where as Figure 2C and Figure 2D shows the 3D profilometry images of the same samples. 
Figure 2 - Visual appearance of indentations formed on the surface of the test pieces subjected to the wear test - A) Control group (Gc); B) Treatment group (Gt); and 3D profilometry images of the same samples - C) Gc; D) Gt.

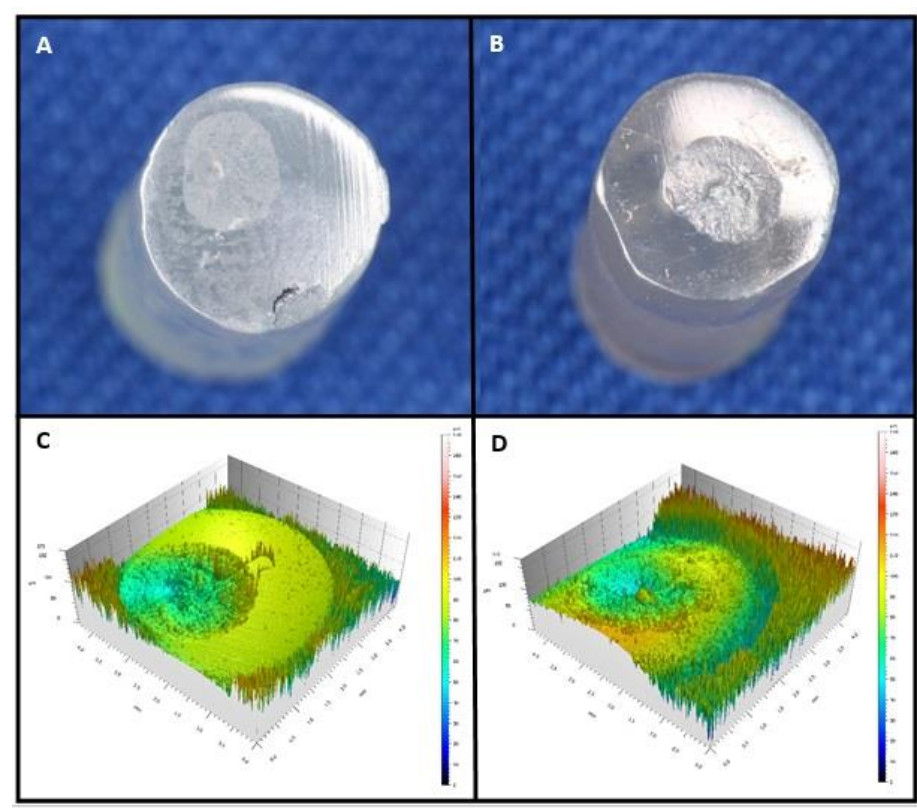

Source: Authors (2022).

As well as Figure 3A and Figure 3B shows the profilometry images of the surface topography of samples without and with coating, respectively.

Figure 3 - Three-dimensional optical profilometry image (20X objective) - A) showing the MCPM surface without DLC film deposition (Gc); B) showing the MCPM surface with DLC film deposition (Gt).

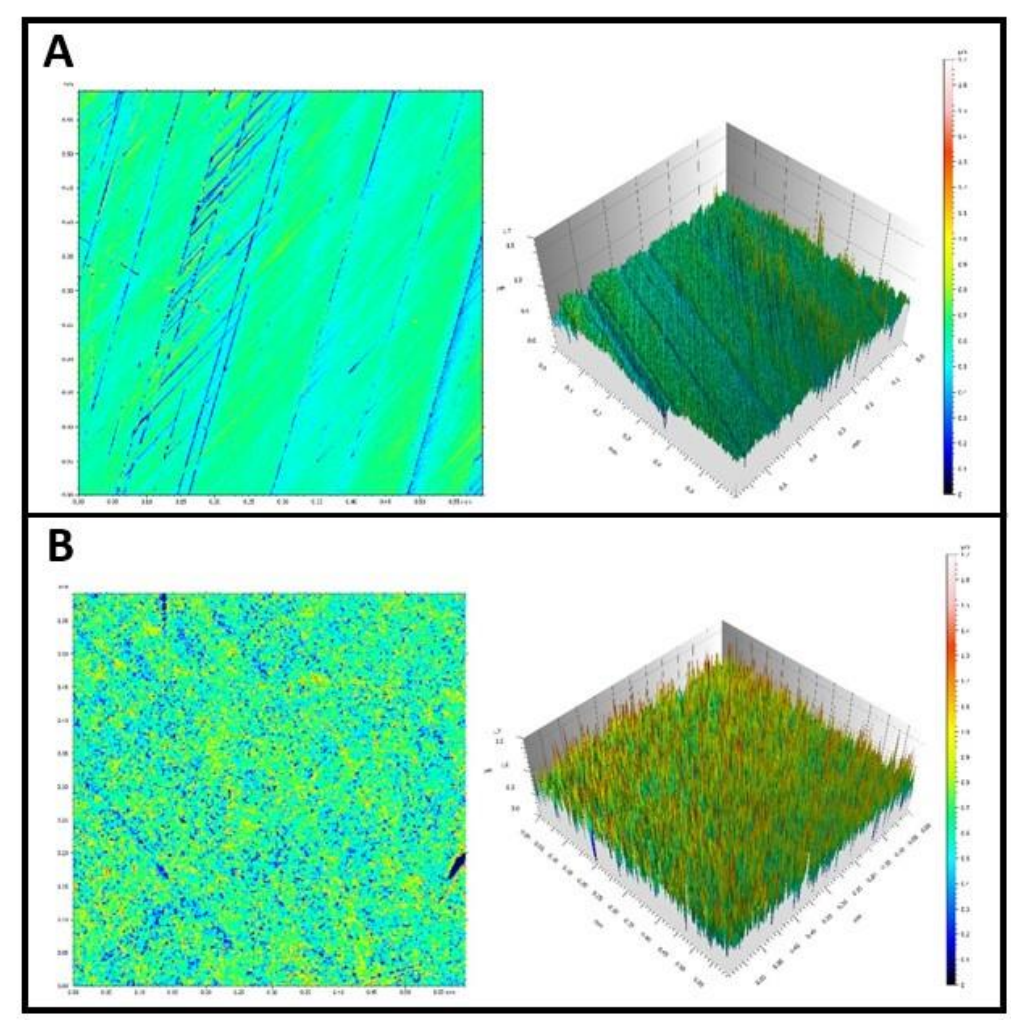

Source: Authors (2022). 


\section{Discussion}

Considering its advantages, such as biocompatibility, low susceptibility to fracture, good light transmission and light weight, PMMA is widely used in dentistry. However, this material has some limitations, including low resistance to abrasion and wear (Barbosa, et al., 2003; Matsumoto, et al., 2008; Ohtake, et al., 2012), and high surface roughness (Machado, et al., 2012). Therefore, coating MCPM with a DLC film aiming to improve these properties (Ban at al., 2009; Ohtake, et al., 2012; Queiroz, et al., 2013) and, thus, increase the useful life of acrylic resin in various dental applications, such as occlusal splints, more extensive dental prostheses, prosthetic teeth, long-term provisional restorations, and acrylic dental arch coatings used to prevent fracture and wear resulting from abrasion due to brushing or bruxism.

We emphasize the limitations inherent to this in vitro study, which did not expose the materials tested to the conditions of the oral environment, along with the methodological difficulties, including performing manual finishing and polishing. However, measures were taken to reduce the possibility of bias by using a single operator in all test piece preparation stages and randomly assigning the test pieces to each group.

Although DLC film is widely used as hard and low friction coating in coating tools, for instance, and few studies have being done using the DLC coating in dentistry, thereby hindering comparisons between the present results and those of other studies.

The ultimate tensile strength of a material is the maximum stress before it undergoes plastic deformation or fracture, and depends on several factors, including the test piece deformation rate, shape and surface finish, and medium in which the test piece is tested. When an external force acts on a body, an opposite reaction of equal magnitude but opposite direction (tension) occurs, generating elastic and/or plastic deformation (Anusavice, 2005).

The three-point flexural strength test simultaneously measures the tensile (force per unit area), compressive and bending strengths of a rod-shaped test piece. The resulting deformation of the test piece is represented by compressive deformation in the upper region (decreased length) and tensile deformation in the lower region (increased length); shear stress occurs at the supported ends of the test piece, but it does not play a key role in the fracture (Anusavice, 2005).

The application of the DLC film to the acrylic resin surface did not increase its flexural strength; however, the mean flexural strength values of the Gc (103.7 MPa) and Gt (101.7 MPa) groups were higher than those required by the ISO 20795 1:2013(E) that regulates this test, according to which the flexural strength of MCPM must not be lower than 65 MPa. The high flexural strength values obtained may be related to the high degree of surface smoothness obtained in the test pieces and to the fact that the test pieces were placed with the DLC film-coated area facing down when performing the test and, therefore, were subjected to tensile stresses, which are predominant in this area. However, the DLC film did not increase the flexural strength values of the acrylic resin. No other study assessing the flexural strength of PMMA coated with a DLC film was found in the literature, thus hindering comparison with the results from the present study.

Wear measurent are related with the volume of material removed from the sample during the relative movement between two surfaces in contact and may occur through adhesion, abrasion or corrosion (Robertson, 2002; Venâncio, 2005). Adhesion is one of the main attributes that a coating/substrate system (in this case, DLC/PMMA) should have (Bordin, et al., 2018; Li, et al., 2000; Silva, et al., 2019; Venâncio, 2005). DLC films usually have high wear resistance because this property varies directly with hardness. Hardness is a measure of the strength of the material against localized plastic deformation and, in the case of DLC, depends on the $\mathrm{sp}^{3} / \mathrm{sp}^{2}$ ratio (Li, et al., 2000; Lin, et al., 2008; Venâncio, 2005).

The mechanical properties of a DLC coating are driven by several factors between them, the deposition method (Bordin et al., 2018). In a study used finite element analysis and step-stress accelerated life-testing to evaluate the stress distribution behavior under loading and to evaluate the probability of survival (reliability) and failure mode of DLC-coated of 
screw of prosthetic abutment for dental implant through two different coating methods, by unbalanced magnetron sputtering or by radio frequency plasma-activated. Both methods increased the hardness and Young's modulus compared to uncoated controls; it did not improve the probability of survival of abutment screws used in an implant-supported crown system. Screw fracture was the chief failure mode regardless of DLC coating method or its absence (Bordin, et al., 2018).

In the present study, no significant difference in wear resistance was found between the groups. A possible explanation for this finding may be the loss of adhesion between the film and the resin, which is corroborated by the indentations formed (assessed by profilometry) and the similar straightness values observed in Gc and Gt. Studies have shown the weak adherence between these materials and have attempted to improve it (Dearnaley et al., 2005; Li, et al., 2000; Lin, et al., 2008; Park et al., 2015; Penkov, et al., 2016). Accordingly, the use of the PECVD method is more efficient than physical deposition (Li, et al., 2000; Lin, et al., 2008). Another alternative would be coating with silicon (Si) (Dearnaley et al., 2005; Lin, et al., 2008; Venâncio, 2005), titanium carbide (Park et al.,2015) or titanium nitride (TiN) (Li, et al., 2000) films together with the DLC film to improve its adherence to the resin or using pretreatment with oxygen plasma (O2) (Matsumoto, et al., 2008), which has also been proposed to improve film adhesion to PMMA. Technical limitations and difficulties accessing equipment precluded the use of these techniques in the present study and are suggested for future studies.

According to what was highlighted recently (Matsumoto, et al., 2008), another factor that may lead to adhesion failure between the DLC and the substrate is the thickness of the film used. Thicker films cause internal stresses during deposition that can lead to their subsequent detachment. In their study, the researchers used a DLC film with the standard thickness of $200 \mathrm{~nm}$ together with titanium carbide film ranging from 0 to $40 \mathrm{~nm}$ thickness, and observed improved adhesion with the increase in TiC thickness. A rougher surface and mechanical damage were observed after mechanical fatigue test in polyethylene samples with 10nm thick DLC film coating (Silva, et al., 2019).

In a study where PMMA substrates were coated with 500-nm-thick DLC and Si films by PECVD, resulting in a total coating thickness of $1 \mu \mathrm{m}$, bias voltages of 100, 150, 250 and $350 \mathrm{~V}$ were used to compare the wear resistance at each voltage (Lin, et al., 2008). The friction coefficient and the wear rate of coated PMMA were lower than those of untreated PMMA and could be related to the higher bias voltages, which generate harder films because of the higher number of $\mathrm{sp}^{3}$ bonds in the structures.

In other study, the DLC protected polyethylene from wear induced through friction of spherical stainless-steel tip (Silva, et al., 2019). This different behavior is possibly explained by the reduction of the friction coefficient by performing the test in a liquid medium, simulating the humid environment of the oral cavity. The saliva could as work as liquid lubricant between the surface of the metallic sphere and the DLC film and contributing to its greater resistance and the counterpart reducing the friction coefficient. We suggest future tests using DLC-PMMA in a humid environment to better elucidate this theory.

Using PMMA substrate coated with DLC and TiN films using bombardment energies ranging from 200 to $1000 \mathrm{eV}$, it has been shown that the friction coefficient of PMMA coated only with a DLC film decreased gradually with the increase in bombardment energy up to the limit of $600 \mathrm{eV}$ (Li, et al., 2000). The PMMA coated with a DLC and TiN film showed similar behavior, albeit with lower friction coefficient values ( $\mathrm{Li}$, et al., 2000). As the time of exposure to wear increased, the friction coefficient values of the untreated group remained constant, whereas those of the treatment group tended to worsen, demonstrating that the films tend to move after a specific period of wear (Li, et al., 2000).

The surface smoothness of the substrate that will be coated with a DLC film is also highly important for optimizing film adherence and preventing the occurrence of surface defects; (Venâncio, 2005; Vionet, 2005) mechanical polishing should be performed until reaching a final surface roughness lower than $1 \mu \mathrm{m}$ (Venâncio, 2005). In the present study, mechanical 
polishing of MCPM test pieces was performed using decreasing grit sandpapers (150, 240, 400, 600 and 1200), as suggested by before (Vionet, 2005), producing a surface roughness well below the recommended values, with a mean of $0.03 \mu \mathrm{m}$, using the technique recommended for clinical dental.

The surface topography changed after DLC film deposition. The superficial demarcated parallel lines, from the polishing process, were covered by homogeneous film. This is corroborating with a study using DLC-coated polyethylene and DLC-coated titanium the superficial cavities each two materials were partially covered by film and discretely reduced (Silva, et al., 2019).

The chemical vapor deposition technique was used because it is an useful method for depositing homogeneous films on materials with complex shape, as it is the case of a dental prosthesis appliance. In a preliminary experiment, the DLC coating was deposited using an ionization deposition method, however, this coating was found to contain defects (Akaike, et al., 2015).

The mean surface roughness $(\mathrm{Ra})$ is the mean of the absolute values of the heights of the peaks and valleys in the sample surface in relation to the center plane (Venâncio, 2005). After coating the acrylic resin with the film, an increase in Ra to $0.10 \mu \mathrm{m}$ was observed. This result contradicts a previous report (Queiroz, et al., 2013) that the Ra remained constant with and without film, with a mean of $0.14 \mu \mathrm{m}$. This behavior may result from differences in the polishing technique applied to the substrate, as the previous study (Queiroz, et al., 2013) used only 320-, 600- and 1200-grit sandpapers; therefore, the Ra of the uncoated surface remained very close to the Ra of the film. Increases in surface roughness when coating with a DLC film were reported by other studies (Asakawa, et al., 2011; Enomoto, et al., 2010), although the polymers studied were not PMMA. It has been recently reported that surface roughness increases as the silver content deposited with the DLC increased (Písařík, et al., 2017).

The results show that although coating increased the surface roughness of the acrylic resin in the present study, the Ra value remained lower than that clinically recommended in the literature, $0.2 \mu \mathrm{m}$ (Chatzivasileiou, et al., 2013), which does not preclude the clinical use of DLC because of the surface roughness. In agreement with a previous study (Queiroz, et al., 2013), the profilometry images show uniform distribution of the film on the surface of the acrylic resin.

A possible explanation for the lack of DLC film effects on the mechanical properties tested (flexural strength and wear) may be the adhesion of the DLC film to the polymeric materials, which is usually lower than that found in ceramic or metallic materials (Tsubone, et al., 2007). In the situation tested in the present study, wherein a composite consisting of a less rigid material as the substrate (PMMA) was coated with a more rigid material (DLC film), the authors state that a complex physical behavior is expected and that when these materials are deformed by mechanical stress, the fracture properties of the thin DLC film should be strongly dependent on the physical and chemical properties of both the substrate and film materials (Tsubone, et al., 2007). Because PMMA is an amorphous polymer (Asakawa, et al., 2011) with low free surface energy (Matsumoto, et al., 2008), it may have problems adhering to the DLC film, which becomes more critical when using tests involving dynamic forces.

Some works demonstrated a higher force in mechanical tests, an increase of the adhesion test and lower wear rate friction in DLC-Ag films presenting many different atomic concentrations of silver (Silva, et al., 2019). Thus, the use of DLC films doped with silver seems to us a promising way to bring mechanical improvements; however, its viability must be evaluated, since we are not working with metallic substrates, but PMMA substrate.

Further studies assessing the effects of factors such as polymer surface treatments, film thickness or static and dynamic loads on the behavior of the PMMA-DLC composite should be performed. The results showed a clear esthetic compromise of the polymer at the thickness tested $( \pm 250 \mathrm{~nm})$. The polymer was brownish but did not lose transparency, which 
could limit the application of the technique to PMMA devices used in esthetic areas, such as artificial anterior teeth.

We emphasize the limitations of a laboratory study and the need for validating the clinical use of DLC in dentistry because, regardless of these results, the coating technique remains unknown in this field, and the costs of its implementation in prosthesis laboratories would still be considered high. Further studies are needed to expand the knowledge on this technique, in the hope of contributing improvements for possible applications of dental devices made from this material.

\section{Conclusion}

It can be concluded that the DLC film surface coating of MCPM had no effect on flexural strength and wear resistance for this material, and DLC film increased MCPM surface roughness by 2.8 times. New studies are suggested to better understand the effects of DLC film on mechanical and surface properties of the MCPM, perhaps with variations in the deposition parameters such as coating thickness or on the sp3/sp2 ratio, in addition, to perform coating-substrate adhesion test.

\section{References}

Akaike, S.; Hayakawa, T.; Kobayashi, D.; Aono, Y.; Hirata, A.; Hiratsuka, M. \& Nakamura, Y. (2015). Reduction in static friction by deposition of a homogeneous diamond-like carbon (DLC) coating on orthodontic brackets. Dent Mater J, 34(6), 888-895.

Anusavice, K. J. (2005). Propriedades mecânicas dos materiais dentários. In Phillips, Materiais Dentários (11th ed., pp. 69-95). Rio de Janeiro: Elsevier.

Asakawa, R.; Nagashima, S.; Nakamura, Y.; Hasebe, T. \& Suzuki, T.; Hotta, A. (2011). Combining polymers with diamond-like carbon (DLC) for highly functionalized materials. Surf Coat Technol, 206, 676-685. doi: 10.1016/j.surfcoat.2011.02.064

Bordin, D.; Coelho, P. G.; Bergamo, E. T. P.; Bonfante, E. A.; Witek, L. \& Cury, A. A. B. (2018). The effect of DLC-coating deposition method on the reliability and mechanical properties of abutment's screws. Dental Materials, 34(6), 128-137. doi: 10.1016/j.dental.2018.03.005

Ban, M. \& Yuhara, T. (2009). Chemical resistance of DLC thin film deposited PMMA substrates. Surf Coat Technol, 203(17/18), 2587- 2590. doi: 10.1016/j.surfcoat.2009.02.051.

Barbosa, D. B.; Souza, R. F.; Lucas, M. G.; Leles, C. R. \& Compagnoni, M. A. (2003). Resistência a flexão de resina acrílica polimerizada pela energia de microondas. Braz Dent Sci, 6(2), 72-79.

Chatzivasileiou, K.; Emmanouil, L.; Kotsiomit, E.; Pissiotis, A. (2013). Polishing of denture base acrylic resin with chairside polishing kits: An SEM and surface roughness study. Int J Prosthodont, 26(1), 79-81.

Cohen, J. (1988). Statistical power analysis for the behavioral sciences. Hillsdale: Lawrence Erlbaum Associates.

Corazza, P. H.; Silva, A. M.; Queiroz, J. R. C.; Marocho, M. S.; Bottino, M. A.; Massi, M. \& Assunção e Souza, R. O. (2014). Carbon film coating of abutment surfaces: Effect on the abutment screw removal torque. Implant Dent, 23(4) 434-438. doi: 10.1097/ID.0000000000000111

Dearnaley, G. \& Arps, J. H. (2005). Biomedical applications of diamond-like carbon (DLC) coatings: A review. Surf Coat Technol, 200(7), 2518-2524. doi: 10.1016/j.surfcoat.2005.07.077

Enomoto, K.; Hasebe, T.; Asakawa, R.; Kamijo, A.; Yoshimoto, Y.; Suzuki, T.; Takahashi, K. \& Hotta A. (2010). Controlling the drug release rate from biocompatible polymers with micro-patterned diamond-like carbon (DLC) coating. Diam Relat Mater, 19, 806-813. doi: 10.1016/j.diamond.2010.01.053

ISO - International Organization for Standardization. (2013). Dentistry - Base polymers - Part 1: Denture base polymers. Geneva: ISO 20795-1(E).

Kiesow, A.; Sarembe, S.; Pizzey, R. L.; Axe, A.S. \& Bradshaw, D. J. (2016). Material compatibility and antimicrobial activity of consumer products commonly used to clean dentures. JPD, 115(2), 189-198.

Li, D. J; Cui, F. Z.; Gu, H. Q. \& Li, W. Z (2000). Ion beam-assisted deposition of DLC films on PMMA and TiN/PMMA. Vacuum, 56(3) $205-211$.

Lin, Z.; Lv, S. B.; Yu, Z. J.; Li, M.; Lin, T.; Ba, D.; Choi, C. \& Lee, I. (2008). Effect of bias voltage on Diamond-like carbon film deposited on PMMA substrate. Surf Coat Technol, 202(22/23), 5386-5389. doi: 10.1016/j.surfcoat.2008.06.071

Lifshitz, Y. (1999). Diamond-like carbon—present status. Diam Relat Mater, 8 (8/9), 1659-1676.

Machado, A. L.; Giampaolo, E. T.; Vergani, C. E.; Pavarina, A. C.; Salles, D. S. L. \& Jorge, J.H. (2012). Weight loss and changes in surface roughness of denture base and reline materials after simulated tooth brushing in vitro. Gerodontology, 29, 121-127.

Matsumoto, R.; Sato, K.; Ozeki, K.; Hirakuri, K. \& Fukui, Y. (2008). Cytotoxicity and tribological property of DLC films deposited on polymeric materials. Diam Relat Mater, 17, 1680-1684. https://doi.org /10.1016/j.diamond.2008.02.027. 
Research, Society and Development, v. 11, n. 3, e10211326271, 2022 (CC BY 4.0) | ISSN 2525-3409 | DOI: http://dx.doi.org/10.33448/rsd-v11i3.26271

Ohtake, N.; Uchi, T.; Yasuhara, T. \& Takashima. (2012) Characteristics of Diamond-like carbon films deposited on polymer dental materials. Jpn J Appl Phys, 51(9), 090128-1/6. doi: 10.1143/JJAP.51.090128

Park, C.; Lee, J. \& Park, Y. S. (2015). Thickness effects of TiC interlayer on tribological properties of diamond-like carbon prepared by unbalanced magnetron sputtering method. J Nanosci Nanotechnol, 15, 9009-9013. doi: 10.1166/jnn.2015.11579

Penkov, O. V.; Pukha, V. E.; Starikova, S. L.; Khadem, M.; Starikov, V. V.; Maleev, M. V. \& Kim, D. (2016). Highly wear-resistant and biocompatible carbon nanocomposite coatings for dental implants. Biomaterials, 102, 130-136. doi: .biomaterials.2016.06.029

Písařík, P.; Jelínek, M.; Remsa, J.; Mikšovský, J.; Zemek, J.; Jurek, K.; Kubinová, S.; Lukeš, J. \& Šepitka, J. (2017). Antibacterial, mechanical and surface properties of Ag-DLC films prepared by dual PLD for medical applications. Mater Sci Eng C, 77, 955-962. doi 10.1016/j.msec.2017.04.005

Procópio, A. L. F.; da Silva, R. A.; Maciel, J. G.; Sugio, C. Y. C.; Soares, S.; Urban, V. M. \& Neppelenbroek, K. H. (2018). Antimicrobial and citotoxic effects of denture base acrylic resin impregnated with cleaning agents after long-term immersion. Toxicology in Vitro, 52, 8-13.

Queiroz, J. R. C.; Fissmer, S. F.; Koga-Ito, C.Y.; Salvia, A. C. R. D.; Massi, M.; Silva Sobrinho, A. S. \& Nogueira Júnior, L. (2013). Effect of Diamond-like carbon thin film coated acrylic resin on Candida albicans biofilm formation. J Prosthodont, 22(6), 451-455. doi:10.1111/jopr.12029

Robertson, J. (2002). Diamond-like amorphous carbon. Mater Sci Eng R, 37, 129-281.

Sharma, R.; Pandey, A. K.; Sharma, N;. Sasmal, D. \& Barhai, P. K. (2010). Diamond like carbon films as a protective surface on PMMA for biomedical applications. Surf Coat Technol, 205(7), 2495-2502. doi: 10.1016/j.surfcoat.2010.09.054

Silva, A. M.; Figueiredo, V. M. G.; Prado, R. F.; Santanta-Melo, G. F.; Ankha, M. V. A.; Vasconcellos, L. M. R.; Silva Sobrinho, A. S.; Borges, A. L. S. \& Nogueira Junior, L. (2019). Diamond-like carbon films over reconstructive TMJ prosthetic materials: Effects in the cytotoxicity, chemical and mechanical properties. JOBCR, 9(3), 201-207.

Sorgini, D. B.; Silva-Lovato, C. H.; Souza, R. F.; Davi, L. R. \& Paranhos, H. F. O. (2012). Abrasiveness of conventional and specific denture-cleansing dentifrices. Braz Dent J, 23(2), 154-159. doi: 10.1590/s0103-64402012000200011

Tsubone, D.; Hasebe, T.; Kamijo, A. \& Hotta, A. (2007). Fracture mechanics of diamond like carbon (DLC) films coated on flexible polymer substrates. Surf Coat Technol, 201, 6423-6430. doi: 10.1016/j.surfcoat.2006.12.008

Venâncio, V. S. (2005). Caracterização de filmes de carbono do tipo diamante para aplicações biomédicas. Dissertation (Mestrado em Ciências em Engenharia Metalúrgica e de Materiais) - Universidade Federal do Rio de Janeiro, Rio de Janeiro.

Vionet, M. Z. (2005). Recobrimentos de carbono amorfo para utilização em limas endodônticas. Dissertation (Mestrado em Ciências em Engenharia Metalúrgica e de Materiais) - Universidade Federal do Rio de Janeiro, Rio de Janeiro.

Ykada, Y. (1994). Surface modification of polymers for medical applications. Biomaterials. 15(10), 725-736.

Zhang, H.; Guo, S.; Wang, D.; Zhou, T.; Wang, L. \& Ma, J. (2016). Effects of nanostructured, diamond-like, carbon coating and nitrocarburizing on the frictional properties and biocompatibility of orthodontic stainless steel wires. Angle Orthod, 86, 782-788. 